\title{
Effect of Melatonin and Insulin on Oxidative Stress in Spleen, Impairment of Adherent Leukocytes Activity and Inflammatory Response in Lps Treated Diabetic Mice
}

\author{
Sangita Sutradhar \\ Tripura University \\ Anindita Deb \\ Tripura University \\ Shiv Shankar Singh ( $\nabla$ shivssbhu@yahoo.co.in ) \\ Tripura University https://orcid.org/0000-0002-1053-1580
}

\section{Research Article}

Keywords: Diabetes, melatonin, insulin, cytokines, oxidative stress, LPS

Posted Date: April 7th, 2021

DOI: https://doi.org/10.21203/rs.3.rs-375834/v1

License: (c) (1) This work is licensed under a Creative Commons Attribution 4.0 International License.

Read Full License 


\section{Abstract}

The present study evaluated the protective effect of melatonin and insulin from LPS and diabetesinduced oxidative stress, impairment of peritoneal leukocyte functions, and inflammation in Swiss albino mice. Diabetes was induced in Swiss albino mice by streptozotocin treatment. Experimental mice were divided into two sets. Set-1 contains control, diabetic, melatonin, insulin, and melatonin+insulin groups of mice. In set-Il, all groups of mice were challenged with a single dose of LPS (50 mg/mice). Lipid peroxidation, antioxidant enzymes (SOD, Catalase, GPx) activity, non-enzymatic GSH level, Nrf2/HO-1 expression, phagocytic index, intracellular ROS generation, and proinflammatory cytokines were measured. Diabetic as well as LPS treated diabetic mice showed significantly increased lipid peroxidation, suppressed antioxidant defence system, and down regulated $\mathrm{Nrf2/HO}-1$ expression in spleen tissues; suppressed phagocytic index and increased ROS generation in adherent peritoneal leukocytes and increased level of circulatory proinflammatory cytokines. Either treatment of melatonin or insulin significantly improved the harmful effects caused by both of LPS treatment and of diabetes in experimental mice. Simultaneous treatment of melatonin and insulin effectively ameliorated the LPS, as well as diabetes, caused oxidative load, impairment of adherent peritoneal leukocyte function, and improved the level of circulatory proinflammatory cytokines. In the present study, we have noted that combined treatment of melatonin and insulin was more effective in attenuation of diabetes and LPS induced devastating effects in laboratory mice. Therefore, the present study may suggest a combinatorial approach in the therapeutic use of melatonin and insulin to improve such devastating conditions.

\section{Introduction}

The bacterial endotoxin lipopolysaccharide (LPS) is a component of cell wall of Gram-negative bacteria. Exposure of LPS induces generation reactive oxygen species (ROS) which leads to oxidative stress. In healthy conditions ROS are generated in controlled manner and as signalling molecules regulate various functions i.e. cell proliferation, inflammation, immune response and stress response [Ma, 2013; Kallapura et al, 2014]. Deficiency of insulin or functional disability of insulin leads to a multifaceted clinical syndrome known as diabetes mellitus (DM) [American Diabetes Association, 2019]. Bacterial lipopolysaccharide caused induction of proinflammatory cascades in diabetic organism which resulted in oxidative stress and hampers bodily immune response.

The pathogenesis of various diabetic complications is said to be contributed by macrophages and other innate immune cells as they are also known to have a pro-inflammatory phenotype [Tesch, 2007]. Antigen induced inflammatory response of an organism leads to an increase in the level of proinflammatory cytokines such as interleukins (IL-1, IL-6 and IL-18) [Dinarello, 2018]. Low level of circulatory cytokines is important to regulate the oxidative damage and interrelated complications in diabetic patients. High blood sugar caused reduced bactericidal function and wound healing capacity of innate immune cells in diabetic patients [Moura et al, 2019]. Spleen is a large lymphatic tissue passed by re-circulating lymphocytes which provoke specific $\mathrm{T}$ or $\mathrm{B}$ lymphocyte-mediated immune reactions. The spleen filters bacteria and viruses out of the blood and stores lymphocytes for release when required [Lewis et al, 
2019]. Functional and morphological alterations in the spleen result in the pathogenesis of diabetes and obesity-related chronic kidney disease [Buchan et al, 2018].

Insulin is essential for the carbohydrate homeostasis, growth, and development of tissues. It stimulates transportation of glucose into the peripheral tissues such as muscles and adipocytes but inhibits gluconeogenesis and glycogenolysis in the liver [Qaid and Abdelrahman, 2016]. The presence of insulin signalling cascade components in macrophages suggests insulin-mediated alterations in macrophages functions [leronymaki, 2019]. Insulin promotes anti-inflammatory Th2 differentiation in CD + lymphocytes mediated by ERK phosphorylation. Insulin receptors are up-regulated in activated both CD $4+$ and $C D 8+T$ cells [Viardot et al, 2007].

Melatonin is known for its anti-inflammatory, anti-oxidative and immunomodulatory properties. Melatonin acts through sensitization of its G-protein coupled receptors named melatonin receptor 1 (MT1) and melatonin receptor 2 (MT2) [Favero et al, 2017]. Melatonin regulates physiological synchronization of glucose metabolism and stimulates insulin secretion (GSIS) [Simões et al, 2016]. Many in vivo and in vitro studies have suggested that melatonin plays an important role in neuro-immunomodulation. Melatonin possesses great functional versatility exhibiting anti-oxidant, oncostatic, anti-aging, and immunomodulatory effects [Calvo et al, 2013].

Pathogenesis of diabetes caused oxidative stress and impaired immune responses. Reports suggested that both insulin and melatonin are having anti-glycaemic effects and protects the organism from harmful effects of hyperglycaemia. But protective effectiveness of melatonin and insulin from harmful effects of bacterial endotoxin in diabetic condition is less understood. Therefore, in the present study we elucidated the effect of melatonin and insulin on oxidative stress, impairment of peritoneal leukocyte function and inflammatory response in LPS treated diabetic mice.

\section{Methodology}

All of the experiments with animals and their maintenance have been done according to the institutional practice and with the framework of CPCSEA (Committee for the Purpose of Control and Supervision of Experimental Animals) and the Act of Government of India (2007) for the animal welfare.

\section{Animal Model}

Healthy Swiss albino mice colony was maintained in appropriate laboratory conditions of light (12 h L:12 h D), temperature $\left(25 \pm 2^{\circ} \mathrm{C}\right)$, and humidity $(55 \pm 5 \%)$. Rice husk was used to make the bed, and mice were permitted ad libitum access to drinking water and typical pellet diet. 10 weeks old healthy male mice (average body weight 25-26g) were selected for the experiment.

\section{Experimental setup}

Diabetes in experimental mice was induced by multiple low doses of STZ administration (Sutradhar et al., 2020). Fifty experimental animals were divided into two sets of experimental groups as follows: 


\section{Set I Set II}

Group-l: Con Group-l: Con + LPS

Group-II: DB Group-II: DB + LPS

Group-III: DI Group-III: DI + LPS

Group-IV: DM Group-IV: DM + LPS

Group-V: DMI Group-V: DMI + LPS

In set I- Control (Con) mice were received ethanolic saline (0.01\%). Group II represents diabetic (DB) mice. Group III represents diabetic mice received insulin (2IU/100g body weight). Group IV represents diabetic mice received melatonin $(100 \mu \mathrm{g} / 100 \mathrm{~g}$ body weight). Group $\mathrm{V}$ represents diabetic mice received both insulin and melatonin. In Set II mice of all the 5 groups were received single dose of LPS ( $50 \mu \mathrm{g} / \mathrm{mice} / \mathrm{ip})$ 24 hours prior to euthanisation. Peritoneal fluid was collected. Blood of each experimental mouse was collected in EDTA vial. Spleen of experimental mice was dissected out and processed for oxidative stress and culture analysis.

\section{Blood glucose determination}

Blood glucose was determined with the help of the ACCU-CHEK Active blood glucose monitoring system.

\section{Determination of lipid peroxidation level in spleen}

Malondialdehyde is a product of lipid peroxidation and was measured based on its reaction with thiobarbituric acid (TBA) following the method of Ohkawa et al [1979]. 10\% homogenate of the spleen was prepared in phosphate buffer. $0.1 \mathrm{ml}$ of tissue homogenate was mixed with $3.3 \mathrm{ml}$ of TBA reagent [containing $8 \%$ SDS, $20 \%$ acetic acid (pH 3.5), $0.8 \%$ TBA and $0.8 \%$ butylated hydroxyl-toluene]. Reaction mixtures were boiled, and the optical density of the supernatant was determined at $532 \mathrm{~nm}$. Lipid peroxidation was expressed in nmol TBARS formed/mg protein of experimental tissues.

\section{Evaluation of superoxide dismutase (SOD) activity level in spleen}

Superoxide dismutase (SOD; EC 1.15.1.1) activity in the spleen of experimental mice was determined by following the method of Das et al [2000]. 10\% homogenates of the spleen tissues were prepared in phosphate-buffered saline $(\mathrm{pH}=7.4) .0 .1 \mathrm{ml}$ of the homogenate was mixed with $1.4 \mathrm{ml}$ of the reaction mixture (containing 50mM phosphate buffer $(\mathrm{pH}, 7.4), 20 \mathrm{mM} \mathrm{L-methionine,} 1 \%$ Triton-X-100, 10mM hydroxylamine hydrochloride, $50 \mathrm{mM}$ EDTA). $50 \mathrm{mM}$ of riboflavin was added to the mixture and exposed to a $20 \mathrm{~W}$ fluorescence lamp. $1 \mathrm{ml}$ of Griess reagent was added and optical density was determined at 543 $\mathrm{nm}$. One unit of enzyme activity is defined as the amount of SOD inhibiting $50 \%$ of nitrite formation under assay conditions and was expressed as SOD activity in $\mathrm{U} / \mathrm{g}$ tissue weight. 


\section{Evaluation of catalase (CAT) activity level in spleen}

Catalase (CAT; EC 1.11.1.6) activity in the spleen of experimental mice was determined by following the method of Sinha [1972], modified by Hadwan [2016]. 10\% homogenate of the spleen was prepared in phosphate buffer $(\mathrm{pH}=7.4)$ and centrifuged. The supernatant was added to a reaction mixture containing $\mathrm{H}_{2} \mathrm{O}_{2}$ and potassium dichromate and boiled in a water bath and centrifuged. The optical density of supernatant was determined at $570 \mathrm{~nm}$ and the decrease in the $\mathrm{H}_{2} \mathrm{O}_{2}$ content was calculated. The activity of CAT was expressed as the amount of $\mathrm{H}_{2} \mathrm{O}_{2}$ degraded per minute.

\section{Evaluation of glutathione peroxidase (GPx) activity level in spleen}

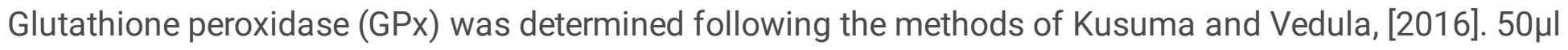
of $10 \%$ spleen homogenate in PBS ( $\mathrm{pH}=7.4)$ was taken in a test tube and mixed with $450 \mu \mathrm{l}$ of water. $2.5 \mathrm{ml}$ of assay mixture $[75 \mathrm{mM}$ Phosphate buffer $(\mathrm{pH} 7.0), 60 \mathrm{mM}$ Glutathione, 30 units/ $\mathrm{ml}$ Glutathione reductase, $15 \mathrm{mM}$ EDTA, $3 \mathrm{mM}$ NADPH] was added to the test tube. $7.5 \mathrm{mM} \mathrm{H}_{2} \mathrm{O}_{2}$ was added to the mixture and absorbance was taken at $340 \mathrm{~nm}$ immediately for 3 minutes. The glutathione peroxidase activity was expressed as moles of $\mathrm{NADP}^{+}$formed/min/mg protein.

\section{Evaluation of reduced glutathione (GSH) level in spleen}

Reduced glutathione (GSH) was determined following the methods of Ellman [1959], modified by Gupta et al [2003]. $10 \%$ homogenate of the spleen was prepared in phosphate buffer $(\mathrm{pH}=7.4)$ and mixed with $20 \%$ trichloroacetic acid in a 1:1 ratio and centrifuged. 200ul of supernatant was mixed with $1.8 \mathrm{ml}$ of Ellman reagent (containing $1 \%$ sodium citrate and $0.04 \%$ DTNB in $0.1 \mathrm{M}$ phosphate buffer $(\mathrm{pH}=8.0)$ ). The optical density of the mixture was determined at $412 \mathrm{~nm}$. The concentration of reduced glutathione was expressed as $\mathrm{mg} / \mathrm{g}$ tissue.

\section{Immunohistochemistry}

Immunohistochemical study of Nrf2 and HO-1 in the spleen was done following the modified methods of Singh et al (2017). Deparaffinized and rehydrated sections were placed in phosphate-buffered saline (PBS) for 30 min. Endogenous peroxidase activity was blocked by $0.3 \% \mathrm{H}_{2} \mathrm{O}_{2}$ in methanol for 30 min at room temperature. Sections were washed with PBS and placed in blocking solution (horse blocking serum, diluted 1:100 in PBS, PK-6200, Vector Laboratories, Burlingame, CA) followed by incubation with primary antibodies [Nrf2; ab31162 and HO-1; ab31163 rabbit polyclonal, Abcam, Cambridge, MA, diluted 1:100] overnight at $4^{\circ} \mathrm{C}$. Sections were washed and incubated with biotinylated secondary antibody (Vectastain ABC Universal Kit, PK-6200, Vector Laboratories, Burlingame, CA, dilution 1:1000). Sections were washed and incubated with preformed $A B$ complex reagent for $30 \mathrm{~min}$. The immune interactions were visualised using the $0.03 \%$ peroxidase substrate 3,3-diaminobenzidine (DAB; Sigma-Aldrich Chemicals, St. Louis, MO) and counterstained with Ehrlich's hematoxylin. Sections were dehydrated and mounted with DPX. Microphotographs of the stained sections were taken under 40X objective in Olympus 
BX-41 Microscope. The specificity of antibodies reactivity was published elsewhere [Sutradhar et al, 2020]. The intensity of immune reactivity was quantified by Image $J$ software.

\section{Isolation of peritoneal macrophages}

The mouse was euthanized and $70 \%$ alcohol was sprayed on its belly region. A small incision was made with a sterilized scissor on the outer skin of the peritoneal cavity and exposes the inner skin of the peritoneal cavity. $5 \mathrm{ml}$ of sterilized PBS was injected in the peritoneal cavity with a 25'gauge needle. Mouse belly region was gently massaged with hand. Nearly $5 \mathrm{ml}$ of peritoneal fluid was withdrawn with 22 gauge of the needle and kept in sterilized $15 \mathrm{ml}$ of the centrifuge tube. The peritoneal fluid was centrifuged and washed with PBS twice and the pellet was resuspended in a culture medium containing $10 \%$ FCS.

\section{Spectrophotometric analysis of ROS level}

The intracellular ROS level in macrophages was measured through spectrophotometric analysis. In spectrophotometry intracellular ROS level in macrophages were determined following the methods of Majewski et al, [2005]. The Peritoneal leukocytes were plated in 96 well culture plates ( $10^{6}$ cells/well) and kept for $1 \mathrm{~h}$ at $37^{\circ} \mathrm{C}$ in a $5 \% \mathrm{CO}_{2}$ incubator. After $1 \mathrm{~h}$ wells were washed with PBS to remove non-adherent cells. $100 \mathrm{ul}$ of NBT $(1 \mathrm{mg} / \mathrm{ml})$ in PBS was added to each well and incubated for another $1 \mathrm{~h}$ at $37^{\circ} \mathrm{C}$ in a $5 \% \mathrm{CO}_{2}$ incubator. After $1 \mathrm{~h}$ medium was discarded and cells were fixed by $70 \%$ methanol and then washed with PBS. The formazan crystals were dissolved by adding $120 \mu \mathrm{l}$ of $\mathrm{KOH}$ and $140 \mu \mathrm{l}$ of dimethyl sulphoxide (DMSO) and absorbance was taken at $630 \mathrm{~nm}$ UV-vis spectrophotometer.

\section{Microscopic analysis of ROS level}

Microscopic analysis of cellular ROS was assessed with the fluorescent probe $\mathrm{H}_{2}$ DCFDA. The peritoneal leukocytes were plated on sterilized clean cover glass in a sterilized petri dish ( $\left.10^{6} \mathrm{cell} / \mathrm{ml}\right)$ and kept for $1 \mathrm{~h}$ at $37^{\circ} \mathrm{C}$ in a $5 \% \mathrm{CO}_{2}$ incubator. After $1 \mathrm{hr}$. of incubation, the cover glass was washed with PBS to remove non-adherent cells. The adherent cells were stained with a $40 \mu \mathrm{M}$ solution of $\mathrm{H}_{2} \mathrm{DCFDA}$ for 30 minutes. Excess dye was washed with PBS and cover glass was mounted on a grease-free slide. The fluorescent images were taken by fluorescence microscope (Leica 2500) at 488nm of excitation emission. The fluorescence generated was measured as corrected total cell fluorescence (CTCF), analysed by Image $\mathrm{J}$ software, and expressed in terms of mean fluorescence intensity [Rastogi and Haldar, 2016].

\section{Evaluation of the change in phagocytic activity of macrophages}

The macrophage phagocytic assay was performed following the method of Roy and Rai [2008]. The heat killed yeast cells suspension was flooded on macrophage monolayer and incubated for 90 minutes. The slides were washed with PBS and fixed with methanol. The methanol fixed slides were stained with 
Giemsa. Random macrophages were counted and Percent phagocytosis was determined by following formula- the number of phagocytic cells per 100 cells.

\section{Determination of proinflammatory cytokine level}

The circulatory level of proinflammatory cytokines (TNFa, IL-1 $\beta$, and IL-6) were measured by commercial kits. TNFa level was determined by murine TNFa ELISA kit, IL-1 $\beta$ was determined by IL-1 $\beta$ ELISA kit and IL-6 level was determined by murine IL- 6 ELISA kit following the manufacturers protocol (Diaclone SAS, France). For TNFa inter-assay and intra-assay coefficient was $9.4 \%$ and $5 \%$ respectively and sensitivity was $10.7 \mathrm{pg} / \mathrm{ml}$. For IL-1 $\beta$ inter-assay and intra-assay coefficient was $>10 \%$ and sensitivity was $4 \mathrm{pg} / \mathrm{ml}$. For IL-6 inter-assay and intra-assay coefficient was $7.2 \%$ and $7.3 \%$ respectively and sensitivity was $10 \mathrm{pg} / \mathrm{ml}$.

\section{Statistical Analysis}

Statistical analysis of the data was performed with one-way analysis of variance (ANOVA) followed by Tukey's honest significant difference (HSD) multiple range test. The differences were considered significant when $p<0.01$. Statistical Package for the Social Sciences (SPSS) and Microsoft Excel program was used for calculation and graph preparation.

\section{Results}

\section{Effect of melatonin and insulin on blood glucose level}

Insulin is well known for reducing blood glucose level. Insulin treated diabetic mice showed significant low glucose level whereas melatonin treatment maintained significantly low blood glucose level in comparison to diabetic mice (Fig. 1). The combined administration of melatonin and insulin caused a substantial drop in blood glucose level in diabetic mice. LPS supplementation caused increase of blood glucose level in all treatment groups in comparison with non LPS treated groups. Combined treatment of melatonin and insulin caused strong suppression of blood glucose level in comparison with either treatment.

\section{Effect of melatonin and insulin on lipid peroxidation level in spleen}

MDA is a reliable marker for detection of lipid peroxidation of membrane lipids and it was measured in terms of nmol TBARS formed per mg protein of spleen. Diabetic mice showed significantly $(p<0.01)$ increased MDA level in the splenic tissue in comparison with the control mice (Fig. 2). LPS treatment to diabetic mice caused significant $(p<0.01)$ increase of the MDA level in the spleen in comparison with diabetic mice. Treatment of melatonin and insulin individually caused significant $(p<0.01)$ decrease of MDA level in LPS supplemented diabetic mice. Simultaneous treatment of melatonin and insulin to LPS treated diabetic mice showed highly significant suppression of MDA level in comparison with other treatment groups. 


\section{Effect of melatonin and insulin on superoxide dismutase (SOD) enzyme activity}

SOD enzyme is an important antioxidant enzyme that responsibly neutralizes superoxide anion formed in the living tissues. Significant $(p<0.01)$ decrease in SOD activity was observed in diabetic mice (Fig. 3 ). LPS administration to diabetic mice caused a significant $(p<0.01)$ decrease in SOD enzyme activity in comparison with diabetic mice. Melatonin and insulin individually caused significant $(p<0.01)$ increase in the SOD enzyme activity in LPS treated diabetic mice. Co-administration of insulin and melatonin showed additive effect in the restoration of SOD enzyme activity in LPS treated diabetic mice.

\section{Effect of melatonin and insulin on catalase (CAT) enzyme activity}

Catalase is an essential antioxidant enzyme that responsibly neutralizes the hydrogen peroxide formed in the living tissues. Significant $(p<0.01)$ suppression of the catalase activity was noted in the spleen of diabetic mice in comparison with the control mice (Fig. 4). LPS treatment to diabetic mice caused significant $(p<0.01)$ suppression of catalase enzyme activity. Significant $(p<0.01)$ increase in the catalase activity was observed in melatonin and insulin treated LPS group of diabetic mice. Concurrent treatment of melatonin and insulin suggestively augmented the catalase activity in LPS treated diabetic mice.

\section{Effect of melatonin and insulin on glutathione peroxidase (GPX) activity in spleen}

Glutathione peroxidase (GPx), a member of the enzymatic-antioxidant defence armoury, is present ubiquitously in the cytosol and mitochondria. GPx detoxifies lipid peroxides by reducing them to their corresponding alcohol and hydrogen peroxide to water. The present study showed that the diabetic group of mice showed significant $(p<0.01)$ low level of GPx activity (Fig. 5). LPS treatment to diabetic mice significantly $(p<0.01)$ suppressed the GPx activity. The individual supplementation of melatonin and insulin significantly $(p<0.01)$ increased the GPx activity in LPS treated diabetic mice. The combined administration of melatonin and insulin showed an additive effect and significantly $(p<0.01)$ increased the GPx activity in LPS treated diabetic mice.

\section{Effect of melatonin and insulin on reduced glutathione (GSH) level}

Glutathione is an important antioxidant and by donating an electron, it reduces hydroperoxide to their corresponding alcohols in living tissues. We observed that diabetic mice showed a significant $(p<0.01)$ reduction in the splenic glutathione level in comparison to the control mice (Fig. 6). However, LPS treatment in diabetic mice further significantly $(p<0.01)$ lowered the splenic GSH level in comparison to diabetic mice. LPS treated diabetic mice showed significant $(p<0.01)$ increase in splenic GSH content 
after melatonin or insulin supplementation whereas combine treatment of melatonin and insulin alleviated the LPS caused suppression of GSH level in spleen of mice.

\section{Effect of melatonin and insulin on $\mathrm{Nrf} / \mathrm{HO}-1$ reactivity in spleen}

Protection against oxidative radicals is given by the expression of antioxidant proteins which are chiefly regulated by the nuclear factor $\mathrm{Nrf} 2$. $\mathrm{HO}-1$ is one of the genes regulate through Nrf2 in the mammalian system. Decreased reactivity of Nrf2 and HO-1 antisera was noted in spleen of diabetic mice. LPS treatment caused decrease in Nrf2 and HO-1 reactivity (Fig. 7, 8). Either supplementation of melatonin or insulin increased the Nrf2 ad HO-1 reactivity in the spleen tissue of LPS treated diabetic mice. The combine treatment of melatonin and insulin effectively reduced the LPS induced changes and increased the Nrf2 and HO-1 reactivity in spleen and diabetic mice.

\section{Effect of melatonin and insulin on cellular ROS of peritoneal macrophages}

Intracellular ROS of peritoneal macrophages can be measured by the amount of NBT converted to waterinsoluble blue formazan crystal by superoxide anions. ROS generation in the diabetic group is significantly $(p<0.01)$ higher in comparison to the control group of mice. LPS treatment to diabetic mice significantly increased the intracellular ROS generation in comparison with diabetic mice (Fig. 9). Individual supplementation of insulin and melatonin significantly $(p<0.01)$ suppressed the ROS level in comparison with diabetic mice. The combined treatment of melatonin and insulin neutralized the adverse effects of LPS and diabetes on intracellular ROS generation and minimized the intracellular ROS to control level.

The intracellular ROS, total oxidative stress generated in the cell at any time point can also be measured with fluorescent compound $\mathrm{H}_{2}$ DCFDA. The total cellular ROS was assessed for adherent peritoneal leukocytes of all treatment groups and reported in terms of mean fluorescence intensity. Diabetic and LPS treated diabetic group showed significant increased $(p<0.01)$ fluorescent intensity in comparison with control mice (Fig. 10). Melatonin and insulin individually reduced the Ros level thus significantly ( $p$ $<0.01$ ) supressed the fluorescent intensity in comparison with diabetic and LPS treated diabetic group as well. Simultaneous supplementation of melatonin and insulin caused significant suppression of fluorescent intensity in comparison with either treatment groups.

\section{Effect of insulin and melatonin on the phagocytic index of macrophages}

Phagocytic activity was assessed by the number of yeast cells phagocytised by the peritoneal macrophages. Significant $(p<0.01)$ decrease in the phagocytic index of macrophage was noted in the diabetic group of mice in comparison to the control group of mice. LPS supplementation to diabetic mice caused significant $(p<0.01)$ suppression of phagocytic index in comparison with diabetic mice (Fig. 11). 
Melatonin and insulin significantly $(p<0.01)$ increased the phagocytic index of macrophages as compared to the diabetic group. Simultaneous supplementation of insulin and melatonin to LPS challenged diabetic mice showed a significant increase in the phagocytic index of macrophages in comparison with other experimental groups of mice.

\section{Effect of insulin and melatonin on the production of proinflammatory cytokines}

Diabetes induction caused a significant $(p<0.01)$ increase in the circulatory level of proinflammatory cytokines TNFa (Fig. 12), IL-1 $\beta$ (Fig. 13), and IL-6 (Fig. 14) in comparison with the control group of mice. LPS treatment to diabetic mice caused a significant $(p<0.01)$ increase in circulatory proinflammatory cytokines level in comparison with diabetic mice. Individual or combined treatment of insulin and melatonin to LPS challenged diabetic mice showed significant $(p<0.01)$ suppression of proinflammatory cytokine levels in comparison with LPS challenged diabetic mice.

\section{Discussion}

An efficient and effective immune response requires increased immune cell proliferation and induces high energy-consuming processes such as biosynthetic and secretory activities of immune cells. Glucose is the most effective energy source for these processes [Pearce et al, 2013]. Diabetes indicates inefficient insulin production or a reduction in insulin sensitivity. In the present study, streptozotocin administration caused $\beta$-cell destruction and reduced the insulin production which results in the persistent hyperglycaemic condition in the diabetic mice. LPS, a bacterial endotoxin activates Toll-like receptor 4 (TLR4) in immune cells and induced release of proinflammatory cytokines which cause inflammation [Ramachandran, 2014]. Present observation showed that LPS administration to diabetic mice caused significant increase in the level of different proinflammatory cytokines. Individual treatment of melatonin and insulin reduced the proinflammatory cytokine levels considerably. Co-implementation of melatonin and insulin caused significant reduction of the inflammatory load in the diabetic mice group. Failure of diabetic mice to stand a considerable inflammatory response may lead to sepsis. The increased inflammatory response also leads higher mortality in diabetic mice [Hassan et al, 2020]. Further, exaggerated or unregulated prolonged inflammatory process can induce tissue damage and is the cause of many chronic diseases [Biswas, 2015].

Inflammation and oxidative stress are closely related to pathophysiological procedures. A critical component of inflammation is the infiltration of inflammatory cells, like neutrophils, monocytes, and lymphocytes [Abdulkhaleq et al, 2018]. In present investigation, significant decreased level of SOD, CAT, GSH, GPx and increased TBARS formation showed high oxidative load in spleen of LPS treated diabetic mice. The treatment of insulin and melatonin simultaneously helped the mice to cope up with this oxidative stress significantly. Individual treatment with insulin and melatonin was also effective in lowering the oxidative load but concurrent treatment of both was more effectively reduced the oxidative load in spleen of studied mice. Studies suggested that an intracellular signalling cascade of 
proinflammatory gene expression can be initiated by free radicals. The report has also suggested that in response to overstated oxidative stress, inflammatory cells can also release reactive species at the site of inflammation [Mittal et al, 2014].

Nrf2 is an important player of cellular redox balance to sustain homeostasis inside the cells. Nrf2 binds to the antioxidant response element (ARE) in the nucleus causing the transcriptional activation of some antioxidant and detoxifying genes [Ishfaq et al, 2019]. GST, HO-1 are few of the antioxidant enzymes which are activated by Nrf2. In the present study we have observed down regulation the Nrf2/HO-1 axis in spleen of LPS treated diabetic mice. Combine treatment of melatonin and insulin effectively minimized the LPS caused suppression of the Nrf2/HO-1 expression in spleen of mice. Recent studies suggested that up-regulation of Nrf2 pathway protects the body from oxidative stress and injuries [Wang et al, 2018]. Diabetes caused down regulation of expression profile of $\mathrm{Nrf} 2 / \mathrm{HO}-1$ in spleen of mice [Sutradhar et al, 2020].

During the inflammatory process, large amounts of reactive oxygen species (ROS) and reactive nitrogen species (RNS) are produced by activated macrophages and neutrophils to kill the invading agents [Kalyanaraman, 2013]. The present study showed that LPS treatment increased the ROS generation in peritoneal leukocytes as detected by using the fluorescent dye, $\mathrm{H}_{2}$ DCFDA. The oxidation of H2DCFA emits an intense green fluorescence. The fluorescence is proportional to the level of ROS generation. Melatonin as antioxidant minimized the level of fluorescence emittance in peritoneal leukocytes. Melatonin in presence of insulin showed high significant suppression of fluorescence. Intracellular ROS generation in peritoneal macrophages can also be measured by the amount of NBT converted to water-insoluble blue formazan crystal by superoxide anions. Diabetes and LPS supplemented diabetes group of mice showed significant higher level of ROS in experimental mice. The action of melatonin and insulin significantly reduced ROS generation. Antioxidant melatonin in presence of insulin more effectively quenched the free radicals and minimized the oxidative stress. During pathological inflammatory conditions excessive generation of reactive species may be induced and the diffusing out of ROS from the phagocytic cells sometime caused localized oxidative stress and tissue damage [Fialkow et al, 2007].

The ability of pathogens to resist the elimination and power of different macrophage stimulators to combat these pathogens can be determined by phagocytic assay. In the present study, phagocytosis was estimated by the number of yeast cells phagocytised by the macrophages. LPS treatment to diabetic mice significantly reduced the phagocytic activity of peritoneal macrophages. Insulin as well as melatonin improved the phagocytic index of peritoneal macrophages while combine treatment highly increased phagocytic activity of peritoneal macrophages. The report suggested that bacterial LPS potentially inhibited phagocytosis of apoptotic neutrophils by peritoneal macrophages [Feng et al, 2011]. Insulin increased the phagocytic activity, $\mathrm{H}_{2} \mathrm{O}_{2}$ production, and glucose metabolism of the macrophages [Costa Rosa et al, 1996]. Melatonin potentiates the phagocytic activity of testicular macrophages in diabetic rats by increasing intracellular free $\mathrm{Ca}^{2+}$ levels [Pawlak et al, 2005]. Further, melatonin also inhibited the expression of various genes (i.e. IL-1 $\beta$, IL-6) induced by LPS in RAW264.7 macrophages [Kadena et al, 2017] and cultured mouse mammary tissue [Yu and Tan, 2019]. 


\section{Conclusion}

Overall experimental data showed that LPS caused aberrations in the diabetic condition led to severe health-related complications. Insulin has been already prescribed as medicine to diabetic patients for glucose uptake by the cells for proper functioning. Increase in the striking role of melatonin's efficiency in amending different abnormalities leads towards its medicinal application in different diseases. The present study showed that melatonin and insulin together effectively restored the LPS induced oxidative stress, impaired peritoneal leukocyte function and inflammatory response in diabetic mice. Therefore, finding of the present study may suggest a combinatorial therapeutic application of insulin and melatonin in such pathological conditions.

\section{Declarations}

\section{Disclosure Statement}

The authors declare that they have no conflict of interest that would prejudice the impartiality of this scientific work.

\section{Acknowledgment}

The authors thank DST-FIST, New Delhi for providing the infrastructural facility to the Department and establishment of State Biotech Hub, Tripura University for extending help.

\section{CRediT authorship contribution statement}

S Sutradhar and A Deb executed the experimental work, data analysis, and compilation of the result and wrote the manuscript. SS Singh conceived the research idea, arranged the funds, provided supervisory support, and revised the manuscript.

\section{Funding}

The work was supported by University Grants Commission New Delhi (Grant No. 39-652/2010 (SR)) and Council of Scientific and Industrial Research, New Delhi (Grant No. 37 (1514)/ 11/ EMR-II).

\section{References}

Abdulkhaleq LA, Assi MA, Abdullah R, et al (2018) The crucial roles of inflammatory mediators in inflammation: A review. Vet World 11(5): 627-635. https://doi.org/10.14202/vetworld.2018.627-635 American Diabetes Association (2009) Diagnosis and classification of diabetes mellitus. Diabetes Care 32: S62-S67. https://doi.org/10.2337/dc14-S081

Biswas SK (2015) Does the interdependence between oxidative stress and inflammation explain the antioxidant paradox? Oxid Med Cell Longev 2016:1-9 (5698931). https://doi.org/10.1155/2016/5698931 
Buchan L, Aubin C R St, Fisher AL, et al (2018) High-fat, high-sugar diet induces splenomegaly that is ameliorated with exercise and genistein treatment. BMC Res Notes 11(1): 752-757. https://doi.org/10.1186/s13104-018-3862-z

Calvo JR, Gonzalez-Yanes C, Maldonado MD (2013) The role of melatonin in the cells of the innate immunity: a review. J Pineal Res 55:103-20. https://doi.org/10.1111/jpi.12075

Costa Rosa LF, Safi DA, Cury Y, et al (1996) The effect of insulin on macrophage metabolism and function. Cell Biochem Func 14(1):33-42. https://doi.org/10.1002/cbf.637

Das K, Samanta L, Chainy GBN (2000) A modified spectrophotometric assay of superoxide dismutase using nitrate formation by superoxide radicals. Indian J Biochem Biophys 37:201-204. http://nopr.niscair.res.in/handle/123456789/15379

Dinarello CA (2018) Overview of the IL-1 family in innate inflammation and acquired immunity. Immunol Rev 281(1): 8-27. https://doi.org/10.1111/imr.12621

Ellman GL (1959) Tissue sulfhydryl groups. Arch Biochem Biophys 82(1):70-77. https://doi.org/10.1016/0003-9861(59)90090-6

Favero G, Franceschetti L, Bonomini F, et al (2017) Melatonin as an anti-inflammatory agent modulating inflammasome activation. Int J Endocrinol 1835195: 1-13. https://doi.org/10.1155/2017/1835195

Feng X, Deng T, Zhang Y, et al (2011) Lipopolysaccharide inhibits macrophage phagocytosis of apoptotic neutrophils by regulating the production of tumour necrosis factor $\mathrm{a}$ and growth arrest-specific gene 6 . Immunology 132:287-295. https://doi.org/10.1111/j.1365-2567.2010.03364.x

Fialkow L, Wang Y, Downey GP (2007) Reactive oxygen and nitrogen species as signaling molecules regulating neutrophil function. Free Rad Biol Med 42(2): 153-164.

https://doi.org/10.1016/j.freeradbiomed.2006.09.030

Gupta YK, Kumar MHV, Srivastava AK (2003) Effects of Centella asiatica on pentylenetetrazole- induced kindling, cognition and oxidative stress in rats. Pharmacol Biochem Behav 74(3):579-585. https://doi.org/10.1016/s0091-3057(02)01044-4

Hadwan MH (2016) New method for assessment of serum catalase activity. Indian J Sci Technol 9: 80499. https://doi.org/10.17485/ijst/2016/v9i4/80499

Hassan F I, Didari T, Khan F, et al (2020) A Review on the protective effects of metformin in sepsisinduced organ failure. Cell J 21(4):363-370. https://doi.org/10.22074/cellj.2020.6286

leronymaki E, Daskalaki MG, et al (2019) Insulin signaling and insulin resistance facilitate trained immunity in macrophages through metabolic and epigenetic changes. Front Immunol 10: Article 1330. https://doi.org/10.3389/fimmu.2019.01330 
Ishfaq M, Chen C, Bao J, Zhang W, Wu Z, et al (2019) Baicalin ameliorates oxidative stress and apoptosis by restoring mitochondrial dynamics in the spleen of chickens via the opposite modulation of NF-KB and Nrf2/HO-1 signaling pathway during Mycoplasma gallisepticum infection. Poult Sci 98(12):6296-6310. http://doi.org/ 10.3382/ps/pez406

Kadena M, Kumagai Y, Vandenbon A, et al (2017) Microarray and gene co-expression analysis reveals that melatonin attenuates immune responses and modulates actin rearrangement in macrophages. Biochem Biophys Res Commun 485:414-420. https://doi.org/10.1016/j.bbrc.2017.02.063

Kallapura G, Pumford NR, Hernandez-Velasco X, Hargis BM, Tellez G (2014) Mechanisms involved in lipopolysaccharide derived ROS and RNS oxidative stress and septic shock. J Microbiol Relat Res 2(1): 6-11.

Kalyanaraman B (2013) Teaching the basics of redox biology to medical and graduate students: Oxidants, antioxidants and disease mechanisms. Redox Biology. 1(1): 244-257. https://doi.org/10.1016/j.redox.2013.01.014

Kusuma PK, Vedula G (2016) In vitro and in vivo antioxidant property of novel 2-Phenyl Quinazoline4(3h)-one derivatives. Biosci Biotech Res Asia 13(2):1121-1132. http://dx.doi.org/10.13005/bbra/2141

Lewis SM, Williams A, Eisenbarth SC (2019) Structure and function of the immune system in the spleen. Sci Immunol 4(33): 1-25. https://doi.org/10.1126/sciimmunol.aau6085

Ma Q (2013) Role of nrf2 in oxidative stress and toxicity. Annu Rev Pharmacol Toxicol 53: 401-426. https://doi.org/10.1146/annurev-pharmtox-011112-140320

Majewski P, Dziwinski T, Pawlak J, et al (2005) Anti-inflammatory and opioid-mediated effects of melatonin on experimental peritonitis in chickens. Life Sci 76: 1907-1920.

https://doi.org/10.1016/j.lfs.2004.04.062

Mishra AP, Yedella K, Lakshmi JB, Siva AB (2018) Wdr13 and streptozotocin-induced diabetes. Nutr Diabetes 8(1):57. https://doi.org/10.1038/s41387-018-0065-6

Mittal M, Siddiqui MR, Tran K, et al (2014) Reactive oxygen species in inflammation and tissue injury. Antioxid Redox Signal 20(7):1126-1167. https://doi.org/10.1089/ars.2012.5149

Moura J, Madureira P, Leal EC, et al (2019) Immune aging in diabetes and its implications in wound healing. Clin Immunol 200: 43-54. https://doi.org/10.1016/j.clim.2019.02.002

Ohkawa H, Ohishi N, Yagi K (1979) Assay for lipid peroxides in animal tissues by thiobarbituric acid reaction. Anal Biochem 95 (2): 351-358. https://doi.org/10.1016/0003-2697(79)90738-3

Pawlak J, Singh J, Lea RW, et al (2005) Effect of melatonin on phagocytic activity and intracellular free calcium concentration in testicular macrophages from normal and streptozotocin-induced diabetic rats. 
Pearce EL, Poffenberger MC, Chang CH, Jones RG (2013) Fueling immunity: insights into metabolism and lymphocyte function. Science 342(6155): 1242454 https://doi.org/10.1126/science.1242454

Qaid MM, Abdelrahman MM (2016) Role of insulin and other related hormones in energy metabolism-A review. Cogent Food Agric 2:1-18. https://doi.org/10.1080/23311932.2016.1267691

Ramachandran G (2014) Gram-positive and gram-negative bacterial toxins in sepsis: a brief review. Virulence 5(1): 213-218. https://doi.org/10.4161/viru.27024

Rastogi S, Haldar C (2016) Comparative effect of melatonin and quercetin in counteracting LPS induced oxidative stress in bone marrow mononuclear cells and spleen of Funambulus pennanti. Food Chem Toxicol 120:243-252. https://doi.org/10.1016/j.fct.2018.06.062

Roy B, Rai U (2008) Role of adrenoceptor-coupled second messenger system in sympathoadrenomedullary modulation of splenic macrophage functions in live fish Channa punctatus. Gen Comp Endocri 155: 298-306. https://doi.org/10.1016/j.ygcen.2007.05.008

Simões D, Riva P, Peliciari-Garcia RA, et al (2016) Melatonin modifies basal and stimulated insulin secretion via NADPH oxidase. J Endocrinol 231(3): 235-244. https://doi.org/10.1530/JOE-16-0259

Singh SS, Deb A, Sutradhar S (2017) Dexamethasone modulates melatonin MT2 receptor expression in splenic tissue and humoral immune response in mice. Biol Rhythm Res 48: 425-435. https://doi.org/10.1080/09291016.2016.1268330

Sinha AK (1972) Colorimetric assay of catalase. Anal Biochem 47(2):389-394. https://doi.org/10.1016/0003-2697(72)90132-7

Sutradhar S, Deb A, Singh SS (2020) Melatonin attenuates diabetes-induced oxidative stress in spleen and suppression of splenocyte proliferation in laboratory mice. Arch Pysiol Biochem https://doi.org/10.1080/13813455.2020.1773506

Tesch GH (2007) Role of macrophages in complications of Type 2 diabetes. Clin Exp Pharmacol 34(10): 1016-1019. https://doi.org/10.1111/dom.12168

Viardot A, Grey ST, et al (2007) Potential anti-inflammatory role of insulin via the preferential polarization of effector T cells toward a T helper 2 phenotype. Endocrinol 148:346-353. https://doi.org/10.1210/en.2006-0686

Wang H, Muhammad I, Li W, Sun X, Cheng P, Zhang X (2018) Sensitivity of Arbor Acres broilers and chemoprevention of aflatoxin B 1-induced liver injury by curcumin, a natural potent inducer of phase-II enzymes and Nrf2. Environ Toxicol Pharmacol 59:94-104. http://doi.org/ 10.1016/j.etap.2018.03.003 
Yu GM, Tan W (2019) Melatonin Inhibits Lipopolysaccharide-Induced Inflammation and Oxidative Stress in Cultured Mouse Mammary Tissue. Mediat Inflam 2019: Article ID 8597159.

https://doi.org/10.1155/2019/8597159

\section{Figures}

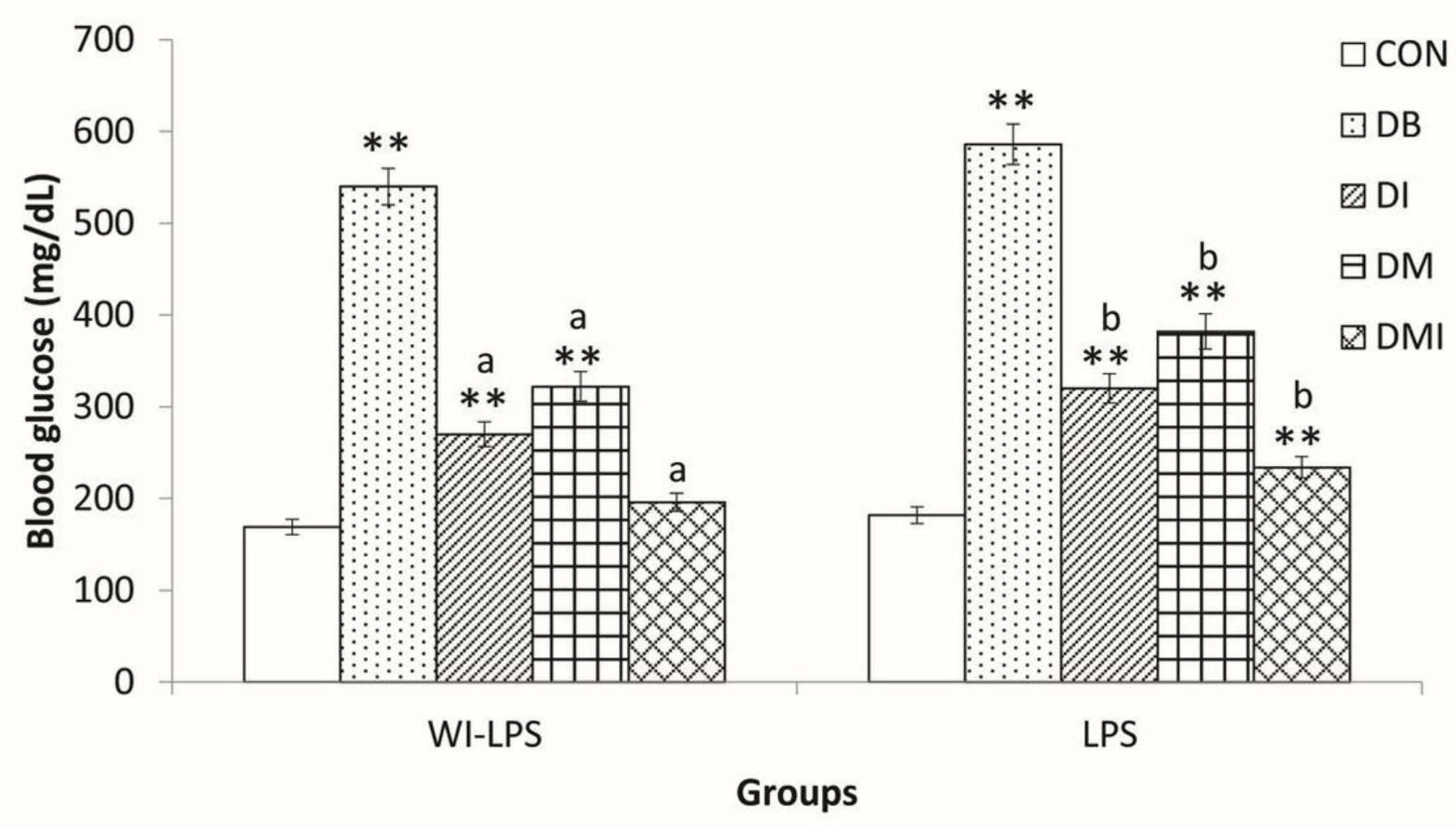

Figure 1

Effect of melatonin and insulin treatment on blood glucose levels in diabetic and LPS treated diabetic mice. Histograms represent Mean $+\mathrm{SEM}, \mathrm{n}=5$ for each group. Con = control, $\mathrm{DB}=$ diabetic, $\mathrm{DI}=$ diabetic mice received insulin, $\mathrm{DM}=$ diabetic mice received melatonin, $\mathrm{DMI}=$ diabetic mice received insulin and melatonin, $D L=$ LPS treated diabetic mice. ${ }^{* *} p<0.01$, Con vs respective group; $a, p<0.01, D B$ vs respective group; $b, p<0.01$, DL vs respective group. 


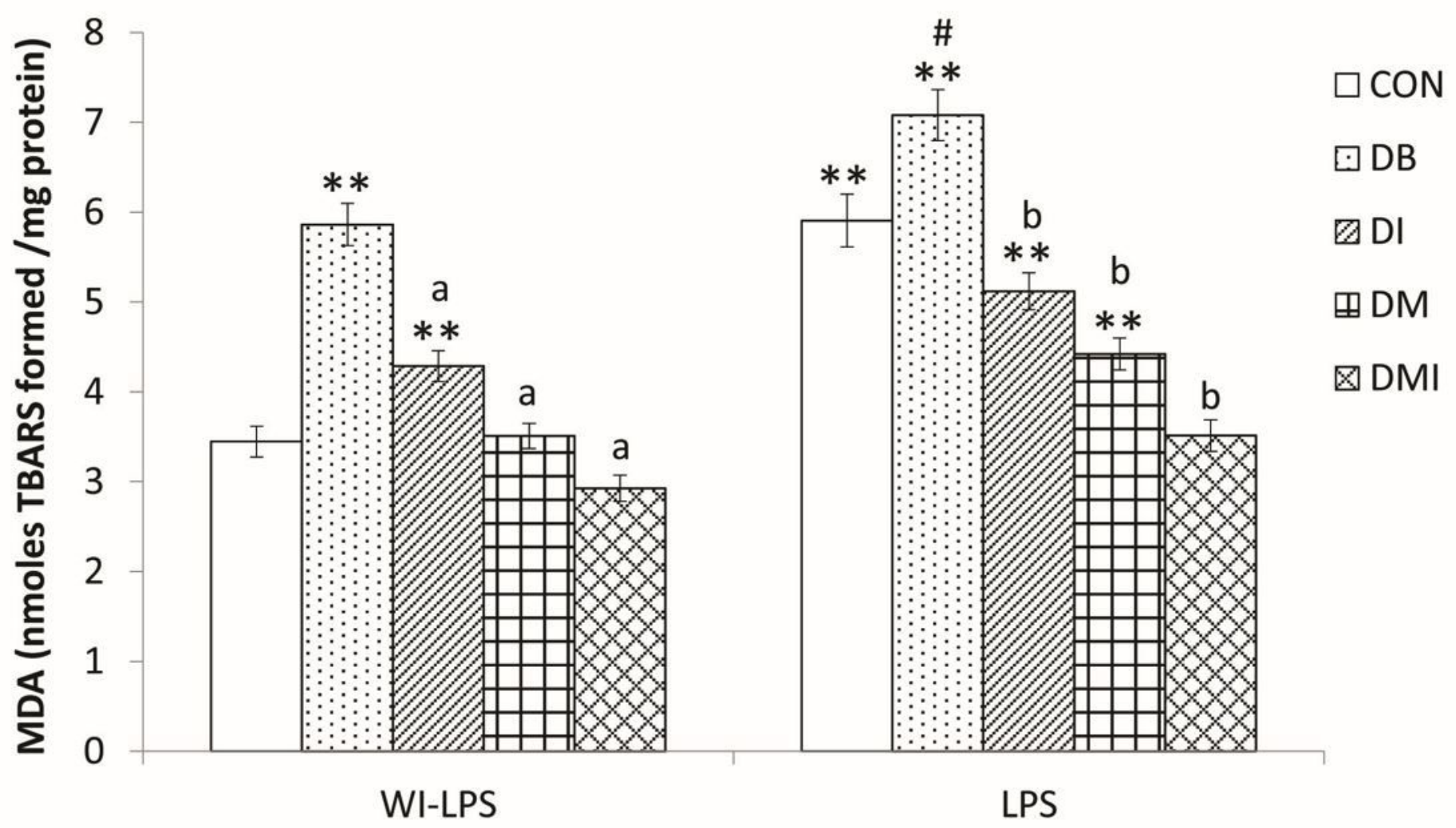

Groups

Figure 2

Effect of melatonin and insulin treatment on lipid peroxidation (MDA levels) in the spleen of diabetic and LPS treated diabetic mice. Histograms represent Mean $+S E M, n=5$ for each group. Con = control, $D B=$ diabetic, $\mathrm{DI}=$ diabetic mice received insulin, $\mathrm{DM}=$ diabetic mice received melatonin, $\mathrm{DMI}=$ diabetic mice received insulin and melatonin, $D L=$ LPS treated diabetic mice. ${ }^{*} p<0.01$, Con vs respective group; a $p<0.01$, DB vs respective group; $b p<0.01, D L$ vs respective group; $\# p<0.01, D B$ vs $D L$ 


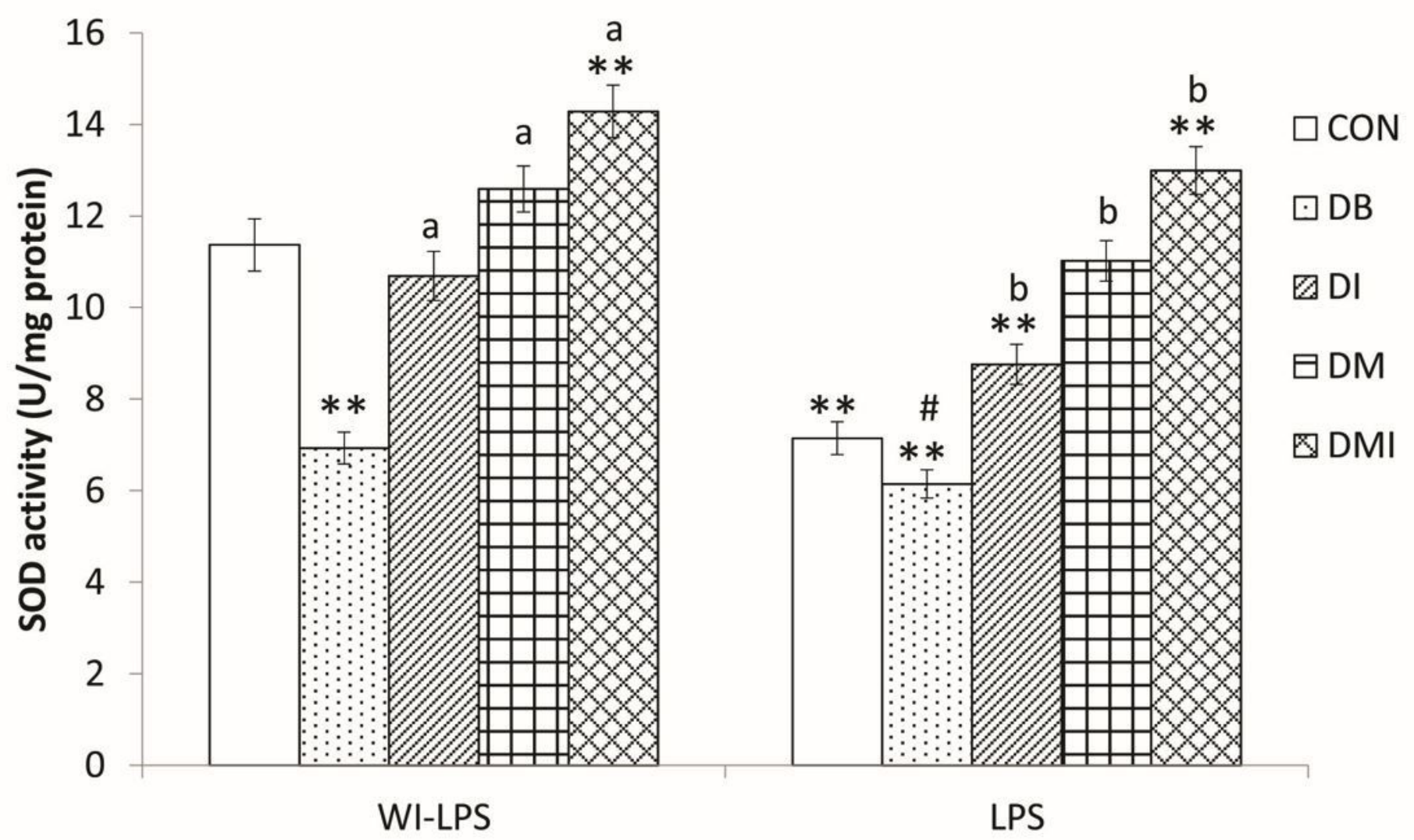

Groups

Figure 3

Effect of melatonin and insulin treatment on super oxide dismutase (SOD) activity in the spleen of diabetic and LPS treated diabetic mice. Histograms represent Mean $+S E M, n=5$ for each group. Con = control, $\mathrm{DB}=$ diabetic, $\mathrm{DI}=$ diabetic mice received insulin, $\mathrm{DM}=$ diabetic mice received melatonin, $\mathrm{DMI}=$ diabetic mice received insulin and melatonin, $D L=$ LPS treated diabetic mice. ${ }^{*} p<0.01$, Con vs respective group; a $p<0.01$, DB vs respective group; $b \mathrm{p}<0.01$, DL vs respective group; \# $p<0.01$, DB vs $D L$ 


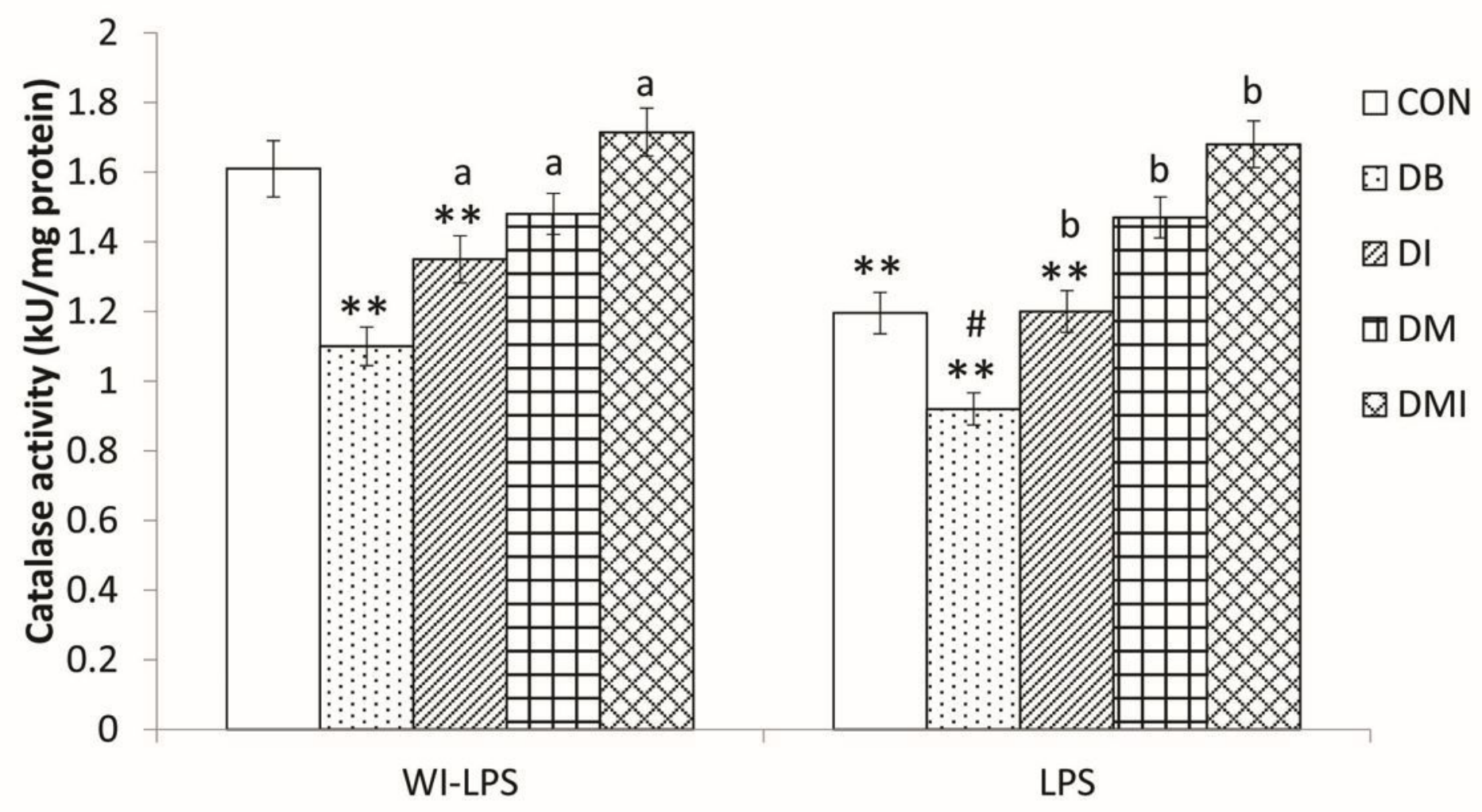

Groups

Figure 4

Effect of melatonin and insulin treatment on catalase activity in the spleen of diabetic and LPS treated diabetic mice. Histograms represent Mean $+\mathrm{SEM}, \mathrm{n}=5$ for each group. Con = control, $\mathrm{DB}=$ diabetic, $\mathrm{DI}=$ diabetic mice received insulin, $\mathrm{DM}=$ diabetic mice received melatonin, $\mathrm{DMI}=$ diabetic mice received insulin and melatonin, $D L=$ LPS treated diabetic mice. ** $p<0.01$, Con vs respective group; a $p<0.01$, DB vs respective group; $b \mathrm{p}<0.01$, $\mathrm{DL}$ vs respective group; \# $\mathrm{p}<0.01, \mathrm{DB}$ vs $\mathrm{DL}$ 


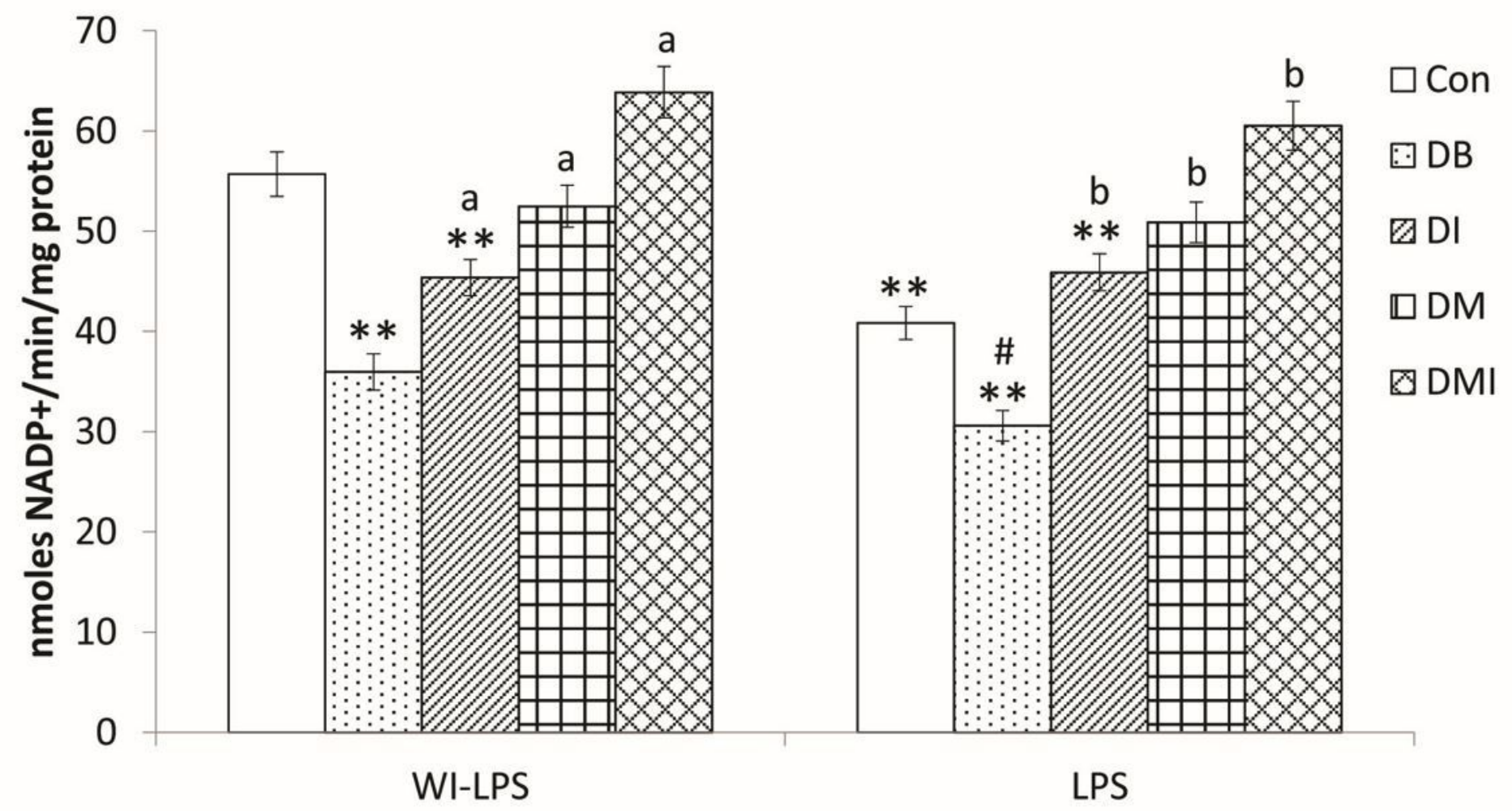

Groups

Figure 5

Effect of melatonin and insulin treatment on glutathione peroxidase (GPx) activity in the spleen of diabetic and LPS treated diabetic mice. Histograms represent Mean $+S E M, n=5$ for each group. Con = control, $\mathrm{DB}=$ diabetic, $\mathrm{DI}=$ diabetic mice received insulin, $\mathrm{DM}=$ diabetic mice received melatonin, $\mathrm{DMI}=$ diabetic mice received insulin and melatonin, $D L=$ LPS treated diabetic mice. ${ }^{*} p<0.01$, Con vs respective group; a $p<0.01$, DB vs respective group; $b \mathrm{p}<0.01$, DL vs respective group; \# $p<0.01$, DB vs $D L$ 


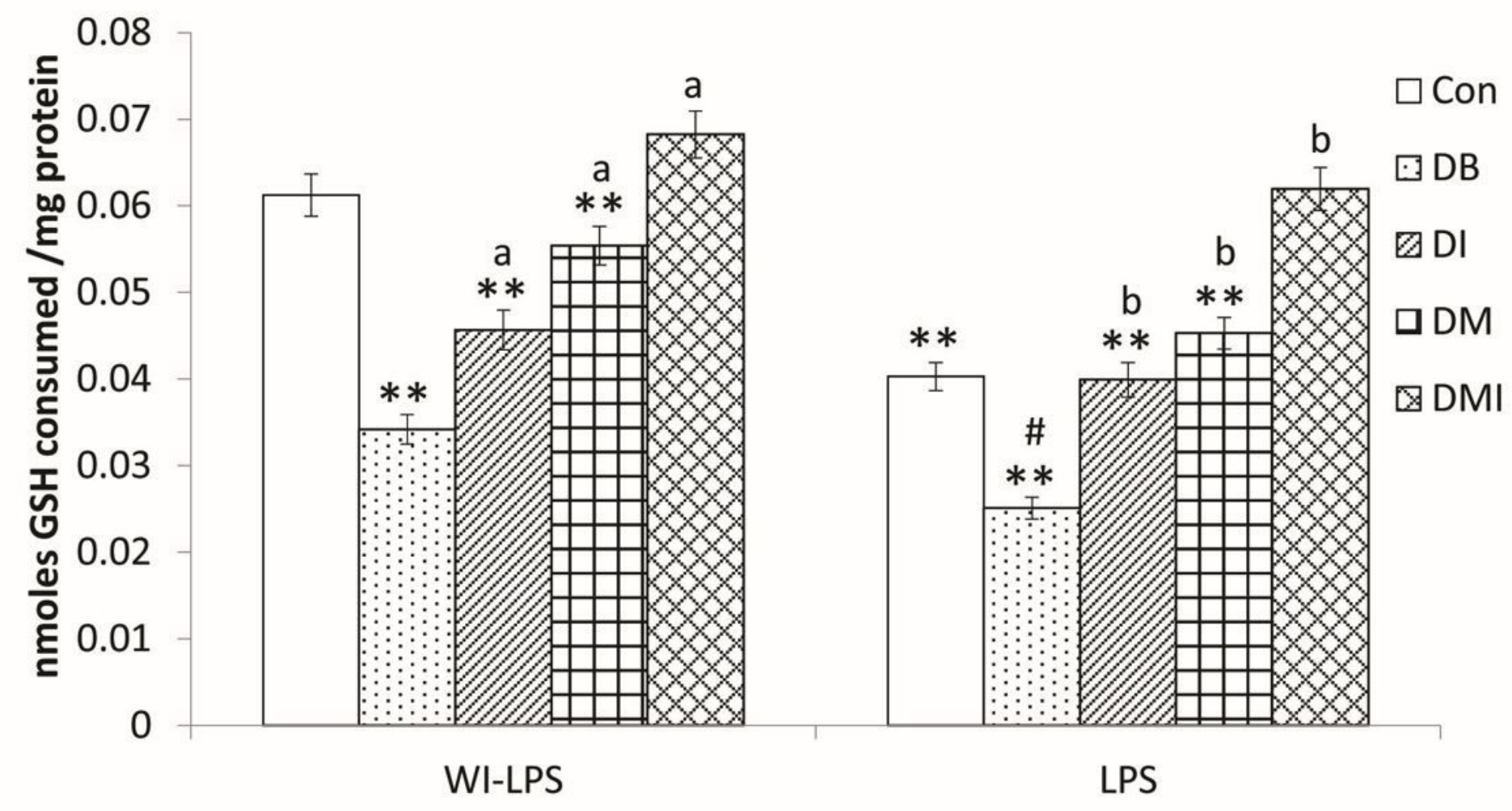

\section{Groups}

Figure 6

Effect of melatonin and insulin treatment on reduced glutathione (GSH) level in the spleen of diabetic and LPS treated diabetic mice. Histograms represent Mean $+S E M, n=5$ for each group. Con = control, $D B=$ diabetic, $\mathrm{DI}=$ diabetic mice received insulin, $\mathrm{DM}=$ diabetic mice received melatonin, $\mathrm{DMI}=$ diabetic mice received insulin and melatonin, $D L=$ LPS treated diabetic mice. ${ }^{*} \mathrm{p}<0.01$, Con vs respective group; a $p<0.01$, DB vs respective group; $b \quad p<0.01, D L$ vs respective group; $\# p<0.01, D B$ vs $D L$ 

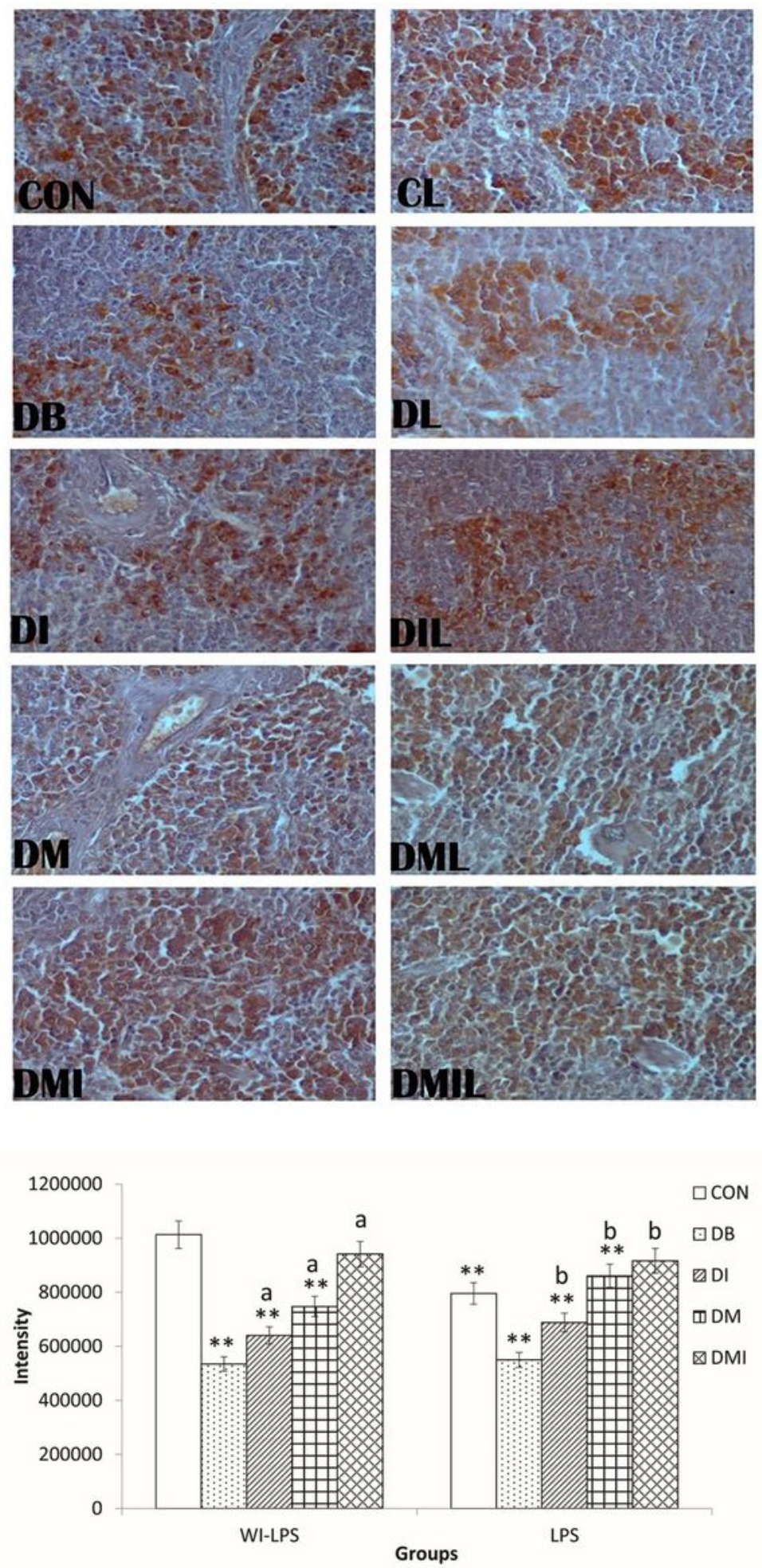

Figure 7

(a) Micrographs showing effect of melatonin and insulin treatment on Nrf2 antisera reactivity in the spleen of diabetic and LPS treated diabetic mice. (b) Histograms showing intensity of immune reactions (Mean + SEM, $n=5$ for each group). Con = control, $C L=$ control + LPS, $D B=$ diabetic, $D L=$ diabetic $+\mathrm{LPS}$, $\mathrm{DI}=$ diabetic + insulin, $\mathrm{DIL}=$ diabetic + insulin + LPS, DM = diabetic + melatonin, $\mathrm{DML}=$ diabetic + 
melatonin + LPS, DMI = diabetic + melatonin + insulin, DMIL = diabetic + melatonin + insulin + LPS. ** $p<0.01$, Con vs respective group; a $p<0.01$, DB vs respective group; $b p<0.01$, DL vs respective group.
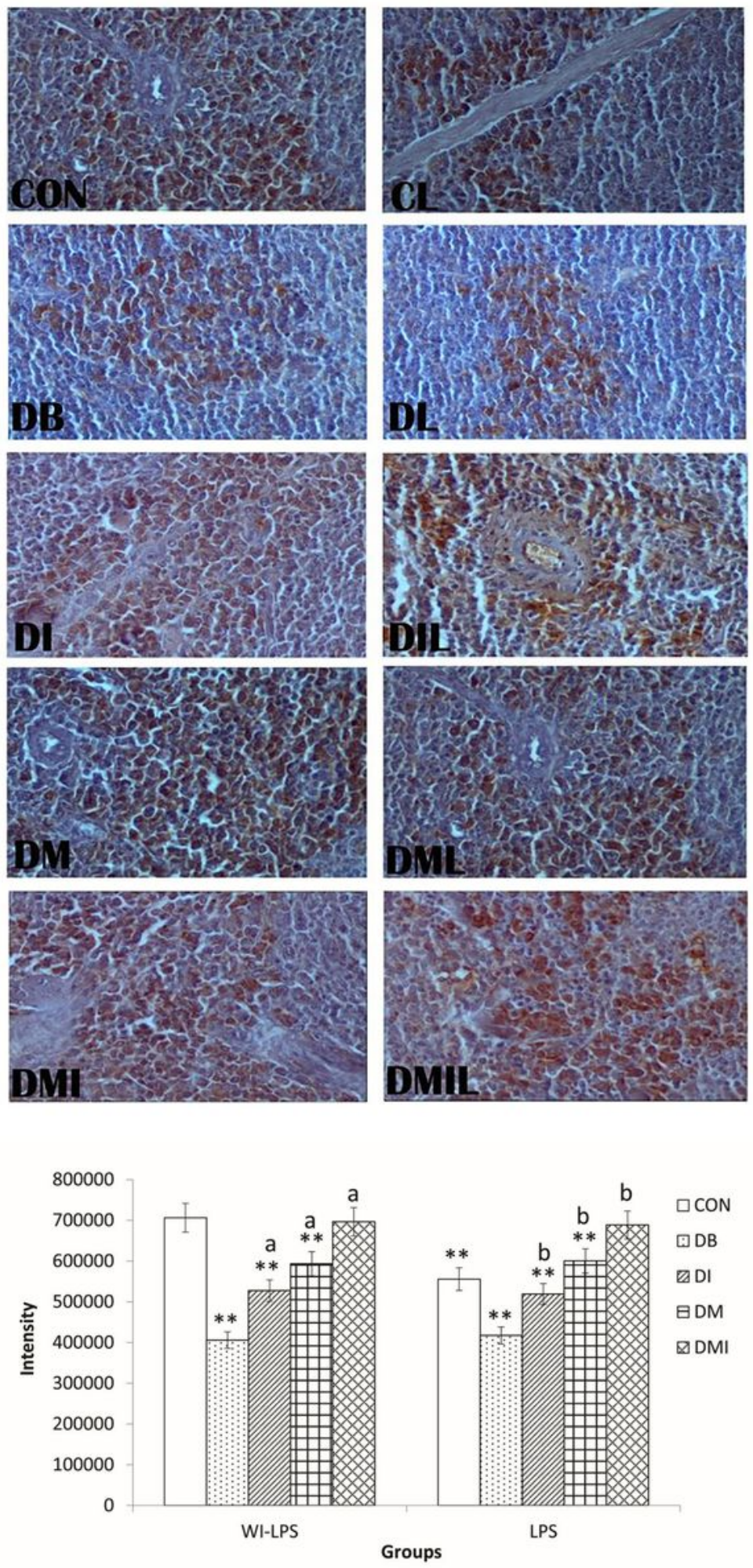

\section{Figure 8}

(a) Micrographs showing effect of melatonin and insulin treatment on HO-1 antisera reactivity in the spleen of diabetic and LPS treated diabetic mice. (b) Histograms showing intensity of immune reactions (Mean + SEM, $n=5$ for each group). Con = control, $C L=$ control + LPS, $D B=$ diabetic, $D L=$ diabetic $+\mathrm{LPS}$, 
$\mathrm{DI}=$ diabetic + insulin, $\mathrm{DIL}=$ diabetic + insulin + LPS, DM = diabetic + melatonin, $\mathrm{DML}=$ diabetic + melatonin + LPS, DMI = diabetic + melatonin + insulin, DMIL = diabetic + melatonin + insulin + LPS. ** $p<0.01$, Con vs respective group; a $p<0.01$, DB vs respective group; $b p<0.01$, $D L$ vs respective group.

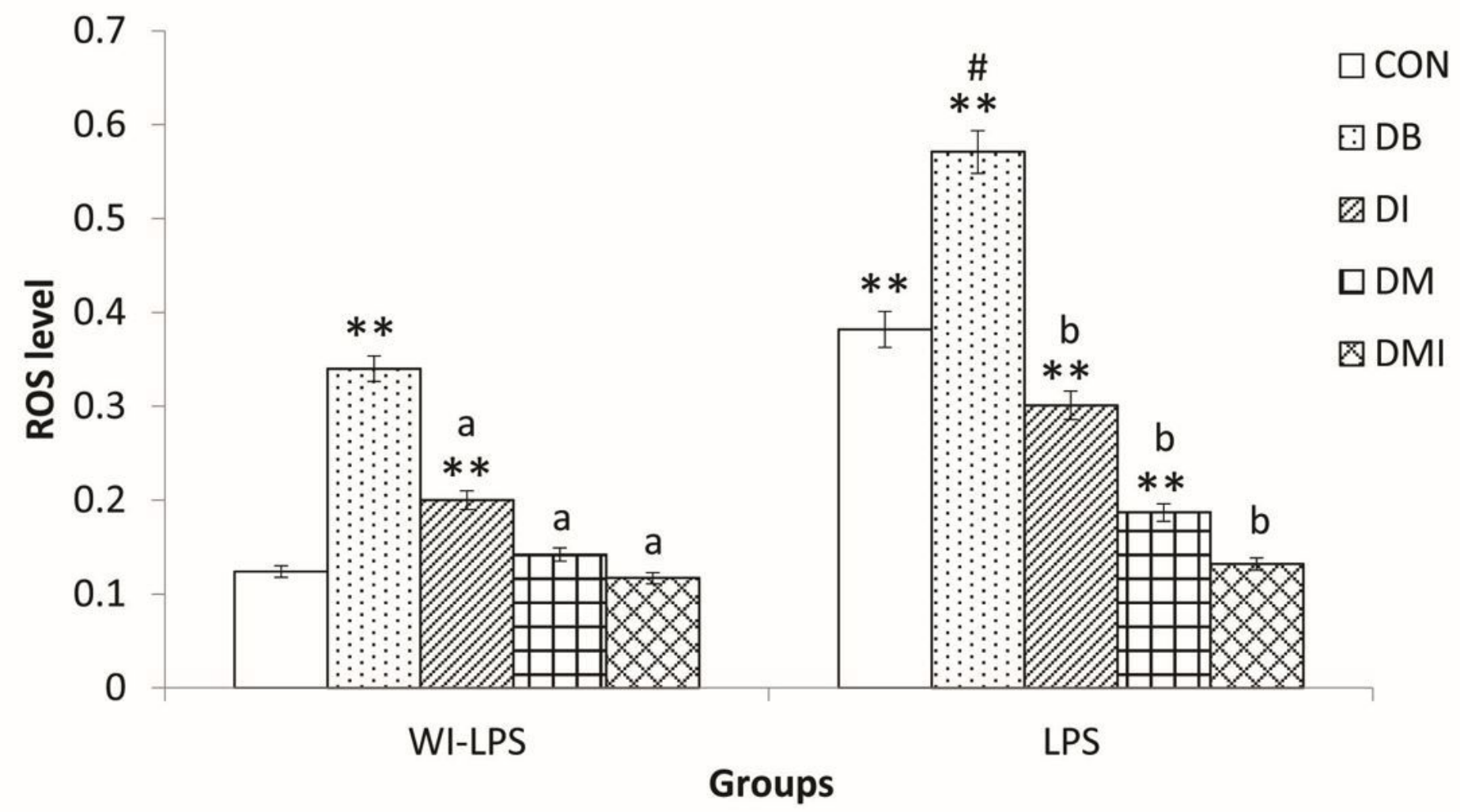

Figure 9

Effect of melatonin and insulin treatment on intracellular ROS generation in adherent peritoneal leukocytes in diabetic and LPS treated diabetic mice. Histograms represent Mean $+S E M, n=5$ for each group. Con = control, $\mathrm{DB}=$ diabetic, $\mathrm{DI}=$ diabetic mice received insulin, $\mathrm{DM}=$ diabetic mice received melatonin, $\mathrm{DMI}=$ diabetic mice received insulin and melatonin, $\mathrm{DL}=\mathrm{LPS}$ treated diabetic mice. ${ }^{* \star} \mathrm{p}<0.01$, Con vs respective group; a $p<0.01$, DB vs respective group; $b \quad p<0.01$, DL vs respective group. 

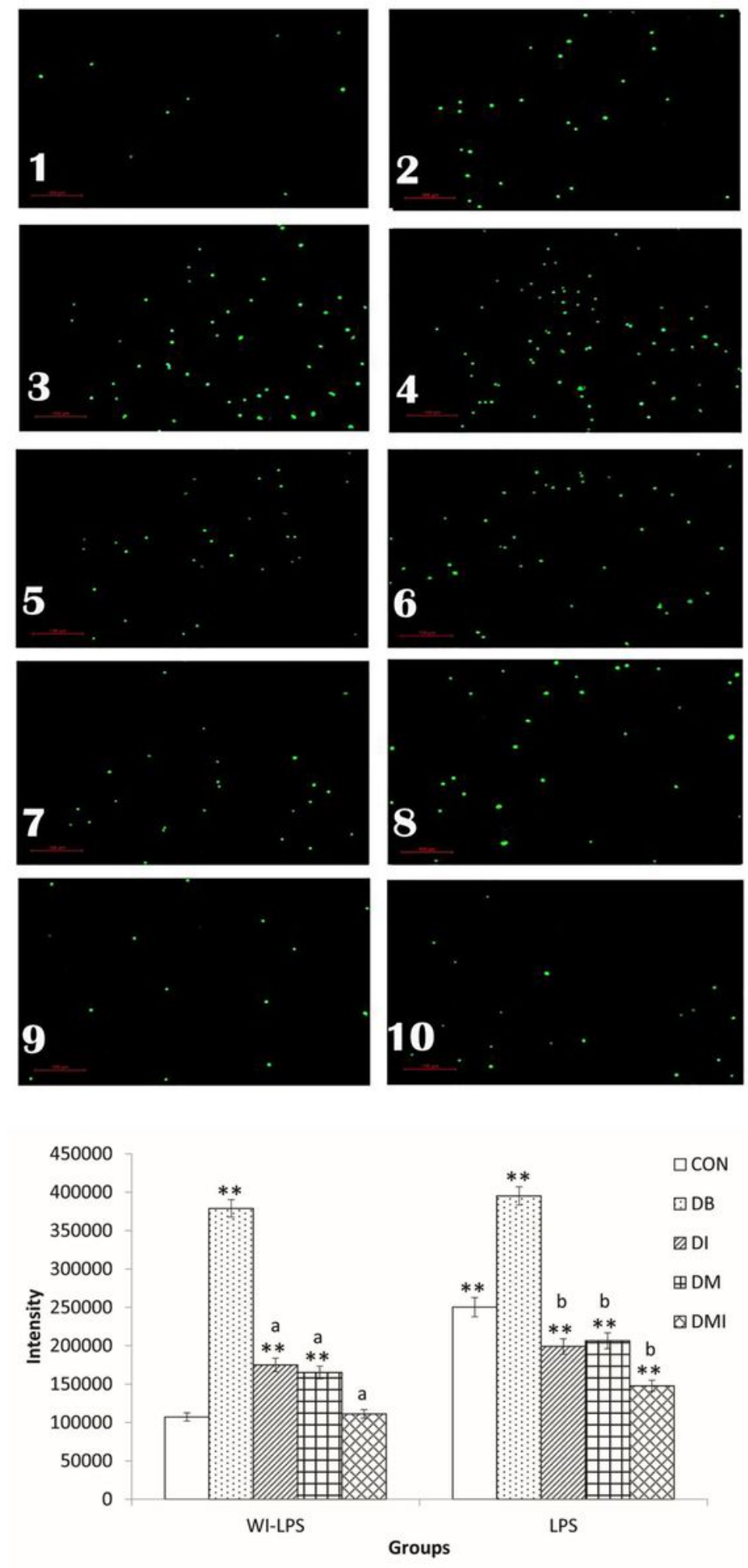

Figure 10

(a) Micrographs showing effect of melatonin and insulin treatment on H2DCFDA fluorescence in adherent peritoneal leukocytes in diabetic and LPS treated diabetic mice. (b) Histograms showing fluorescence intensity (Mean $+\mathrm{SEM}, \mathrm{n}=5$ for each group). 1 , Con = control, $2, \mathrm{CL}=$ control $+\mathrm{LPS}, 3, \mathrm{DB}=$ diabetic, 4, DL = diabetic + LPS, 5, DI = diabetic + insulin, 6, DIL = diabetic + insulin + LPS, 7, DM = diabetic + melatonin, 8, DML = diabetic + melatonin + LPS, 9, DMI = diabetic + melatonin + insulin, 10, 
DMIL = diabetic + melatonin + insulin + LPS. ${ }^{\star}$ p $p<0.01$, Con vs respective group; a $p<0.01$, DB vs respective group; $b \mathrm{p}<0.01$, DL vs respective group.

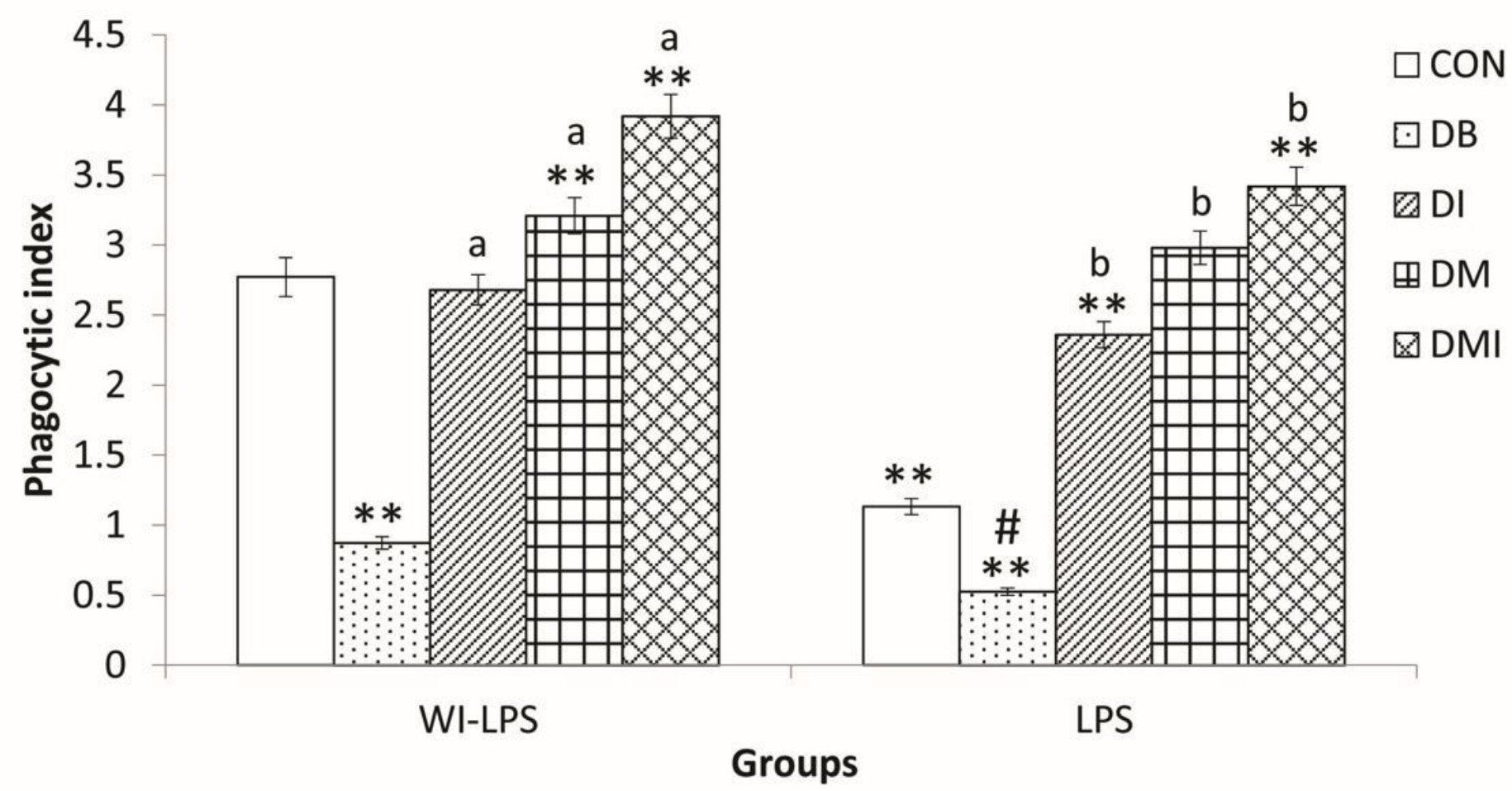

Figure 11

Effect of melatonin and insulin treatment on phagocytic activity of peritoneal macrophages of diabetic and LPS treated diabetic mice. Histograms represent Mean $+S E M, n=5$ for each group. Con $=$ control, $D B$ = diabetic, $\mathrm{DI}=$ diabetic mice received insulin, $\mathrm{DM}=$ diabetic mice received melatonin, $\mathrm{DMI}=$ diabetic mice received insulin and melatonin, $D L=L P S$ treated diabetic mice. ${ }^{*} \mathrm{p}<0.01$, Con vs respective group; a $p<0.01$, DB vs respective group; $b p<0.01$, DL vs respective group; \# $p<0.01, D B$ vs $D L$ 


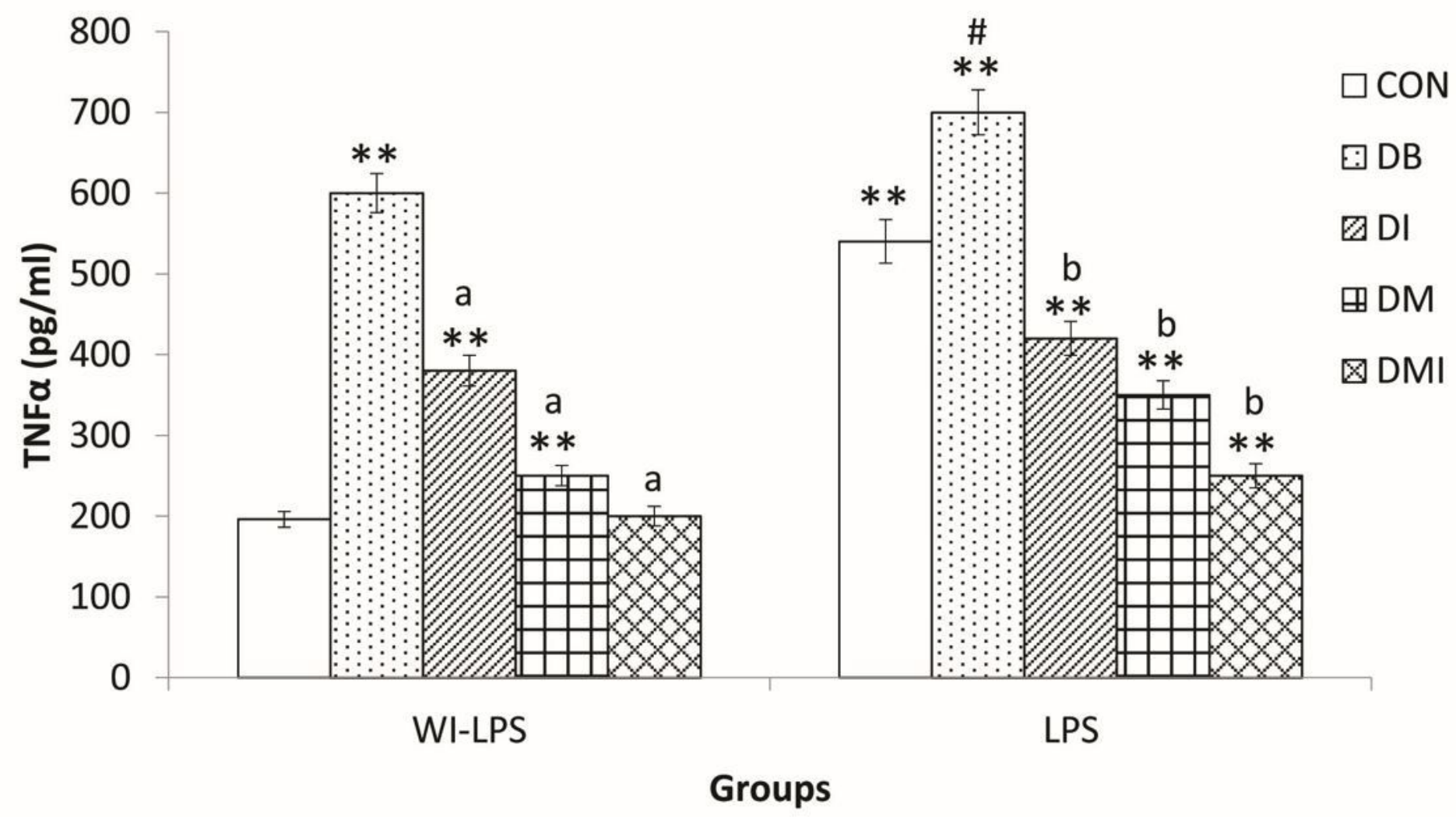

Figure 12

Effect of melatonin and insulin treatment on circulatory TNFa level in diabetic and LPS treated diabetic mice. Histograms represent Mean $+\mathrm{SEM}, \mathrm{n}=5$ for each group. Con = control, DB = diabetic, DI = diabetic mice received insulin, $\mathrm{DM}=$ diabetic mice received melatonin, $\mathrm{DMI}=$ diabetic mice received insulin and melatonin, $\mathrm{DL}=\mathrm{LPS}$ treated diabetic mice. ${ }^{*} \mathrm{p}<0.01$, Con vs respective group; $\mathrm{p}<0.01$, DB vs respective group; $b \mathrm{p}<0.01$, DL vs respective group; \# $p<0.01$, DB vs $D L$ 


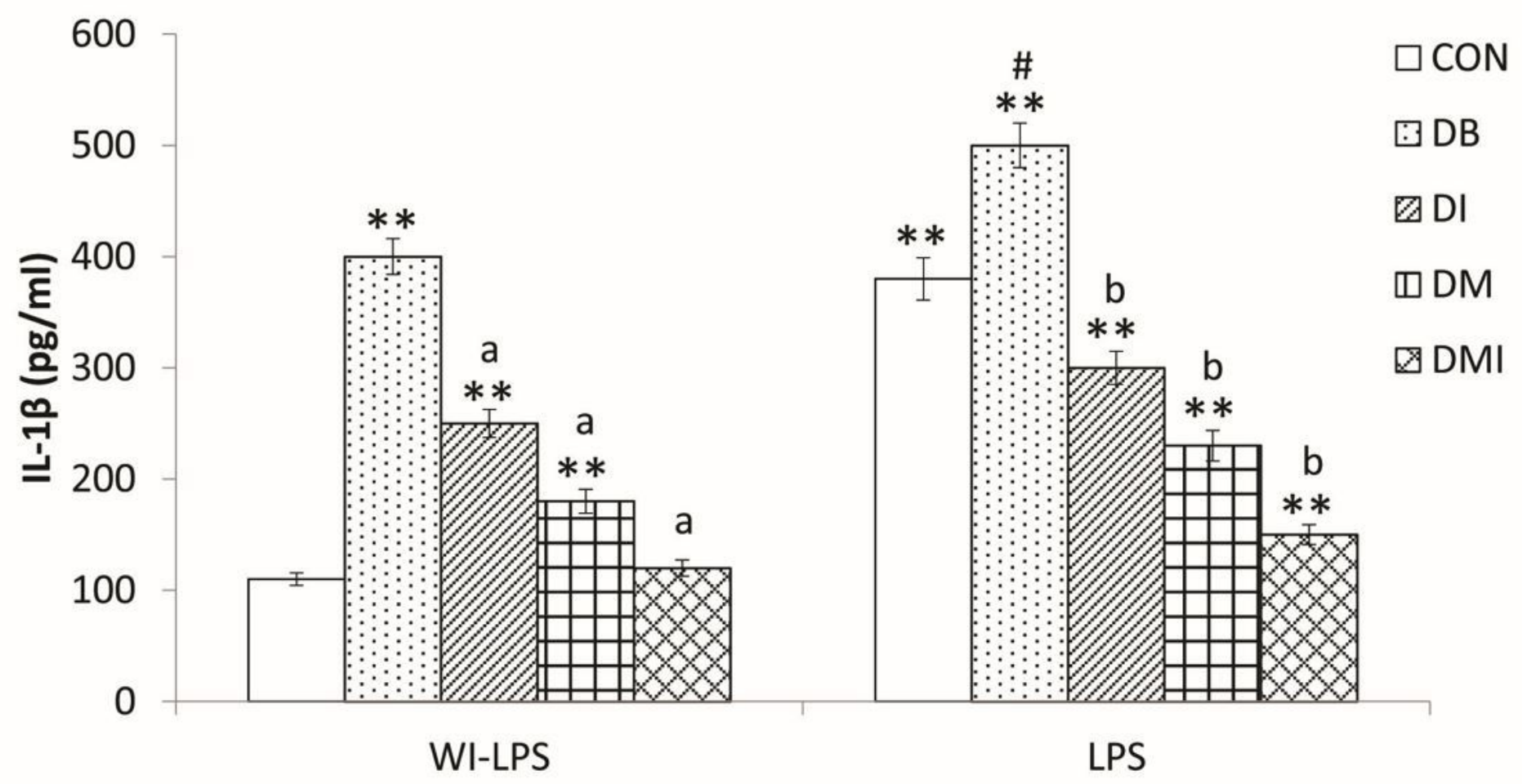

Groups

\section{Figure 13}

Effect of melatonin and insulin treatment on circulatory IL-1 $\beta$ level in diabetic and LPS treated diabetic mice. Histograms represent Mean $+\mathrm{SEM}, \mathrm{n}=5$ for each group. Con $=$ control, $\mathrm{DB}=$ diabetic, $\mathrm{DI}=$ diabetic mice received insulin, $\mathrm{DM}=$ diabetic mice received melatonin, $\mathrm{DMI}=$ diabetic mice received insulin and melatonin, $D L=L P S$ treated diabetic mice. ${ }^{*} p<0.01$, Con vs respective group; $a<0.01, D B$ vs respective group; $b$ p $<0.01$, DL vs respective group; \# $p<0.01$, DB vs DL 


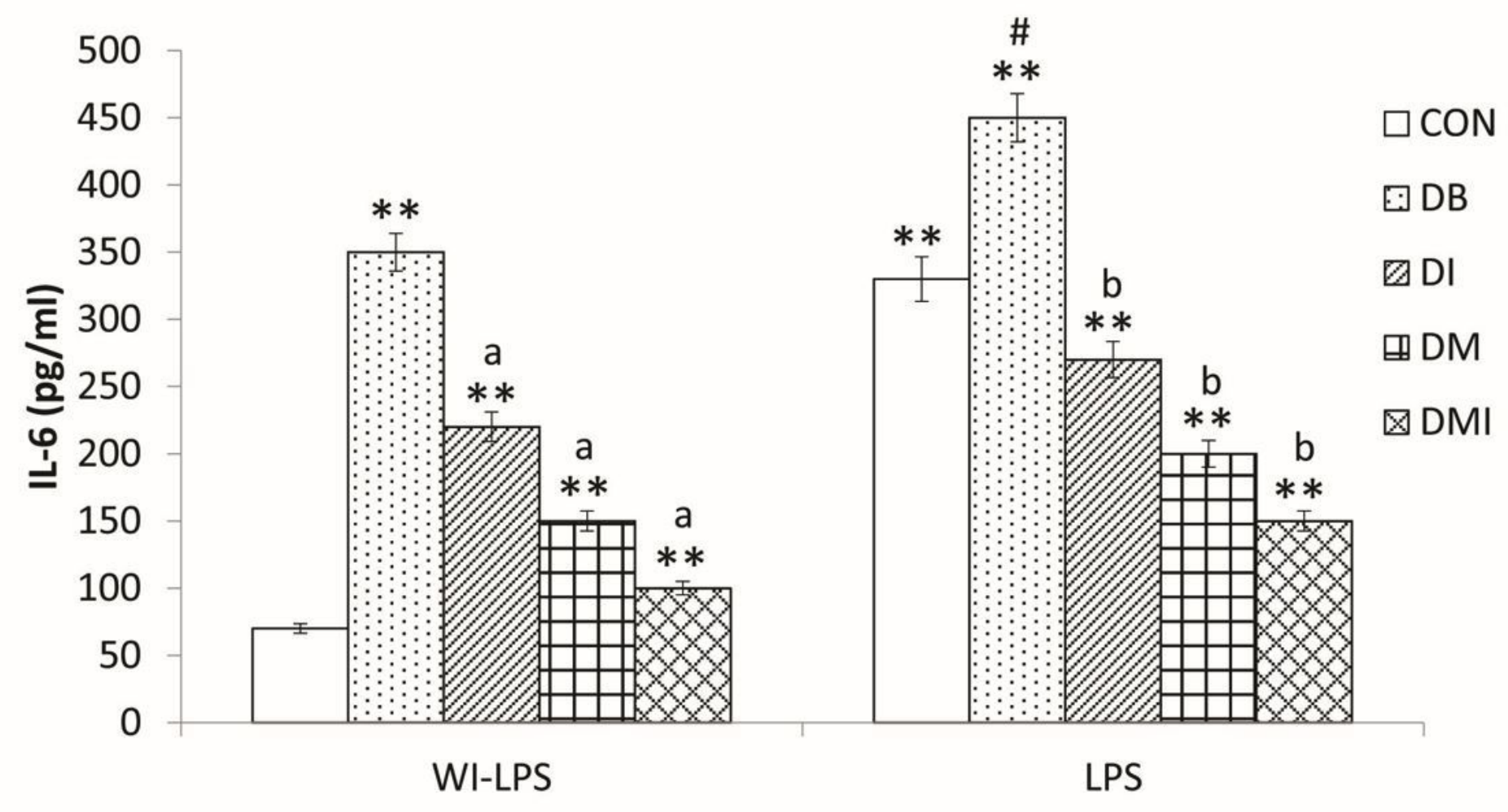

Groups

\section{Figure 14}

Effect of melatonin and insulin treatment on circulatory IL-6 level in diabetic and LPS treated diabetic mice. Histograms represent Mean $+\mathrm{SEM}, \mathrm{n}=5$ for each group. Con $=$ control, $\mathrm{DB}=$ diabetic, $\mathrm{DI}=$ diabetic mice received insulin, $\mathrm{DM}=$ diabetic mice received melatonin, $\mathrm{DMI}=$ diabetic mice received insulin and melatonin, $D L=$ LPS treated diabetic mice. ${ }^{*} p<0.01$, Con vs respective group; $a<0.01, D B$ vs respective group; $b \mathrm{p}<0.01$, DL vs respective group; \# $p<0.01$, DB vs $D L$ 